\title{
Jacqueline Woodson's narrative style in The Other Side: An African American picture book for children
}

\author{
Agustín Reyes Torres \\ Agustin.Reyes@uv.es \\ Universitat de València, Spain
}

\begin{abstract}
The Other Side (2001) is a children's story with multicultural characters and themes that can be regarded as an aesthetic exploration of the human experience in the process of the acquisition of knowledge. Following the Black Arts Movement, Jacqueline Woodson's work portrays many of the issues that are present in the real world but seldom appear in children's literature, such as racial division or interracial relationships. Using the metaphor of a fence, this African American author reveals issues of loneliness and friendship, inclusion and exclusion, and the overcoming of prejudice and segregation through the wisdom of Clover and Annie, an African American and a white girl, who become friends. The story is told from the point of view of Clover who is both the protagonist and the first person narrator. The reader, thus, gets to see and understand the world through her eyes.
\end{abstract}

Keywords: African American, Jacqueline Woodson, Picture book, Children, Segregation

"The content of a story and how it is told are inseparable"

Henry James

Writers who make powerful statements in their stories communicate their ideas through the artistic and skillful use of language. While there is considerable controversy among literary theorists and critics as to how to define literature, there is common agreement regarding the crucial role that language plays in it. As Gillian Lazar’s puts it, literature can be understood as "those novels, short stories, plays and poems which are fictional and convey their message by paying considerable attention to language which is rich and multi-layered” (1993: 5). It is through language that literature provides relevant source material for identifying and examining human motives; readers can see into the mind of the character or even into the subconscious that the very same character does not know. Through the writer's careful choice of language we come to see the current environment, the details from the past and the imaginary world of the character, in other words, the character's motivation for action. Literature thus, through language, gives 
form to the experience of the ongoing cycle of life; it explores the nature of human beings and their particular circumstances. What happens then when the nature and the circumstances of some cultural minorities differ from those consistently represented in mainstream literature? How does literature represent the voices of the so-called cultural minorities, their values and perspectives? The aim of this article is to study how the African American writer Jacqueline Woodson makes use of her narrative style to represent in children's terms the experience of a black girl growing up in the United States and coming to terms with the racial reality. In her book The Other Side (2001), she reorients children's literature, raising racial concerns and eliciting strong emotional responses in the reader.

Woodson's work includes many of the issues that are present in the real world but seldom appear in children's literature, such as racial division, child abuse or interracial relationships. Like many other Black American authors, she shares the experience of being a member of a society in which race matters a great deal. In this sense, her writing for children is clearly rooted in an African American and American social and literary history that can be traced all the way back to the $19^{\text {th }}$ Century. Since then, as Rudine Sims Bishop argues, "the racist [and] stereotypical books about Blacks, created by benighted White writers and artists, made it imperative to create an African American literature to contradict and counteract such imagery” (2007: xiv). African American children's literature developed thus as a literature of social action. It emerges from the very oral culture (songs, stories, rhymes, etc) created by enslaved Africans to form and pass on a set of moral and spiritual values, to instruct each other, to build community and to entertain themselves. As Bishop puts it,

\begin{abstract}
African American children's literature has roots in African American's determination to maintain a sense of themselves as fully human in the face of their legal status as property and to maintain some control over their own lives. Where literacy was forbidden and denied to African Americans, story and song flourished and served to entertain, to discipline, to provide information, to subvert slaveholders' intentions, and to transmit to children the values and attitudes that the community deemed necessary for its survival. (2007: 4)
\end{abstract}

Gradually, as the number of African Americans that had access to freedom and literacy increased throughout the $19^{\text {th }}$ century, some newspapers and periodicals launched by black religious people appeared as vehicles for self-definition, self-determination and self-expression. Some of them such as The Recorder (1852) included readings for children. These publications, along with others created towards the end of the century in 
which the participation of black women became highly significant such as Our Women and Children Magazine (1888), shared a similar goal, making evident their concern for children's literary and education, and most importantly, like Woodson does in The Other Side, establishing their determination to create and display their own African American perspective.

This interest in children's literature among African Americans would be cultivated and strengthened during the first half of the $20^{\text {th }}$ Century with the emergence of intellectuals and writers such a W.E.B. Du Bois, Mary Effie Lee, Langston Hughes, and Arna Bontemps among others. While Du Bois created the renowned magazine for Black children, The Brownies' Book (1920-1921), and Lee and Hughes published in it their first poems, Bontemps became one of the most important authors that the Harlem Renaissance left to African American children's literature (Bishop 2007: 45). Over the course of his prolific forty-year career from the 1930s to the late 1960s, his work not only developed and refined some of the traditions that had begun with The Brownies' Book (a focus on fostering black children's education and see themselves as normal), but also took them a step further. As Bishop highlights,

Bontemps interjected a Black perspective on Black subjects, Black themes, and Black traditions, many of which were carried over from adult African American literature into American children's literature, an arena in which such a perspective was sorely needed. (2007: 52).

This approach set up the basis for the growth and national recognition of other upcoming African American writers and picture book illustrators such as Jacob Lawrence's with Harriet and the Promised Land (1968), John Steptoe with Stevie (1969) or Jacqueline Woodson, who also instilled a black perspective in their work and their characters. In one interviewed in 1987, Steptoe observed: "What I try to create are all the things I didn't have as a kid that I would have liked to read" (Natov and DeLuca 1987: 126). As we will see, these words coincide with Woodson's ideas and aims for herself as a writer. In this case, both authors agree on the need of more children's books through which African American young readers can relate to the protagonists. In words of Neal Lester, "all children need to see possibilities and to see themselves in all possibilities” (Smith 2008). Self-validation for them comes from seeing themselves and acknowledging difference in the pages of the books they read. 
Certainly, one of the characteristics of Woodson's books is that her main characters are African American children, so we get to see and understand the world from their particular perspective. As Rose Casement points out, “in many books that include relationships across races, the white child is in a position of social power. That is not the case in many of Woodson's stories, where the black child is generally situated in the more powerful position within the relationship” (2003: 81). In an interview with the author, she commented: "Sometimes people are surprised that the relationships and situations aren't stereotypical. I wanted to write my side of the story. I grew up reading the white side, which surprisingly to some people, isnt the only side” (Casement 2003: 81). Like many other black writers and critics such as W.E.B. Du Bois, Arna Bontemps, John Steptoe, Violet J. Harris, Patricia Hill Collins, bell hooks, Cornell West and Laretta Henderson among others, Jacqueline Woodson considers that literature and politics have always been linked for the African American community. In her essay "Fictions” she states “...as a woman who is African American, my whole world is political so of course my writing is. [...] It become writing where a reader recognizes a part of themselves and because of this, knows that they are not alone in the world. Writing where the reader's life is legitimized and by extension, the reader is legitimized” (Woodson 2001b: 48). Woodson clearly labels her work political, yet not the kind of didactic political writing that discourages the reader from recognizing himself or herself. Her books for children enable many young African American readers to free their minds of the idea that they are not alone. She articulates the stance that literature can be uplifting and heal the individual. In the past, despite the effort of many African American intellectuals to change it, numerous white authors created novels that contributed to institutionalize the image of blacks as infantile, unintelligent, comical, and ugly (Bishop 2007, Harris 2007, hooks 2003, Manuel 2009, Tolson 2008). Many black children found themselves thus surrounded by children's literature dominated by white representation in books written and illustrated by white authors and illustrators. For Woodson, that must change and there is still much work to be done. Like her African American predecessors, she believes that literature for young black readers should uplift and elevate rather than degrade. That is why her books portray values that promote acceptance of oneself, acceptance of others, pride, moderation, and commitment to family and community. 
According to Laretta Henderson, children's literature written by African Americans should follow the critical discourse and canon created by the Black Art Movement that focuses its attention on the black community as the audience of black art (2005: 301). Although a final ideology is always a compendium of different voices, this movement, which arose in the late 1960s, "moves toward educating the African American community to its collective and differing histories; reflects the community and its culture and concerns; and addresses their social, spiritual and physical needs" (Henderson 2005: 301). Jacqueline Woodson's, in this way, aligns herself with the African American literary tradition and follows the combination of political orientation, audience, content, literary elements and style that defines the black aesthetic. However, she does not fall in the controversial issue of Afrocentrism placing African and African American culture at the center of knowledge. As Patricia Collins, Cornel West and bell hooks criticize, afroncentricity sometimes may lead to essentialize blackness and engage as a result in reverse racism. Woodson does not do this. As it will be shown, in The Other Side, she embraces W.E.B. Du Bois' idea of double consciousness highlighting throughout the story the importance for black children of being aware of both their African ancestry and their purely American identity. Moreover, she pursues the maxim expressed by Du Bois when he conceived The Brownies’ Book by which he called for a literature that would be "adapted to colored children, and indeed to all children who live in a world of varied races” (Cited in Bishop 2007: 35).

The Other Side is a picture book in which Woodson shows the many discoveries that children can make through literature. It is a story made real through the inclusion of universal complexities within the specific cultural experiences that impact young readers. Using the metaphor of a fence, she reveals issues of loneliness and friendship, inclusion and exclusion, and the overcoming of prejudice and segregation through the wisdom of Clover and Annie, an African American and a white girl, who become friends. The author raises simple questions such as: What is the purpose of a fence? What are people like? Why are they like that? What make white and black people do what they do? Can you be friends with a person of a different race? A glimpse of answers to these questions are made visible through Woodson's poetic language and narrative style by the elements of plot, character, point of view, setting, and tone of an 
imaginative work. The other question remaining to be discussed is who is the target audience of this book? Is The Other Side a reading only intended for black children?

As many of the picture storybooks written for younger readers, The Other Side depicts children facing situations and problems that are common to all young children. In spite of its brevity, only twenty-nine pages, Woodson manages to create an engaging plot, to develop Clover's full character, and to show with words and pictures an integral setting in which a number of relevant themes are revealed such as children's curiosity, friendship, family, race and prejudice. The other important aspect to be considered is that the story is told from the point of view of a young African American girl: Clover. She is both the protagonist and the first person narrator. The reader, thus, gets to see and understand the world through her eyes. This is important not only because as a black girl she represents the figure of the "Self" and not the "Other", but also because as we will see, she breaks old stereotypes regarding the traditional portrayal of African American characters.

To begin with the analysis of the narrative style, let us examine the plot and how the author's choice of words introduces the reader in the story and the character's reality. The plot revolves around the presence of the fence that separates the town where Clover lives. Woodson portrays Clover's growing awareness of the world that surrounds her and how she gradually becomes more observant. The opening line of the book is: "That summer the fence that stretched through our town seemed bigger” (Woodson 2001a: 2). By using the demonstrative pronoun "that" at the beginning of the sentence, emotional meaning and attention are draw to the fact that that particular summer was a crucial one in her childhood. The structure pattern of starting a phrase with the words "that summer” is repeated later throughout the story adding significance and impact to the term. It was that summer, we can then interpret, when Clover discovered, and experienced for the first time, that there was racial tension between black and white people and that they were expected to occupy different spaces in society.

In the same way, within the very first page the reader has also access to the setting as well as the initial conflict of the story: Clover is a young African American girl between the ages of eight and ten who lives with her family on one side of that fence; on the other side lives a white family. To create tension, we hear Clover's mom saying: "Don't 
climb over that fence when you play” (Woodson 2001a: 2). But to Clover, the reason for this is not so clear. We can imagine her young mind wondering why if there are white people on that other side, she cannot go there. Her mom does tell her that it is not safe, but this (the unknown) only spurs more intrigue and perplexity. Why is it not safe? This is the question that any young reader may ask himself or herself when reading the beginning of this book.

As the story line progresses, the conflict and the tension increases when Clover sees a young white girl sitting on that fence. The latter even shows interest in playing with her and her African American friends, but to them this white girl, who lives on the other side of the fence, only represents a mysterious threat so they feel afraid of her. They have been taught to keep a distance from that world on that other side so they continue to do so. Clover, however, feels more and more intrigued. Woodson's style holds the reader's interest by creating suspense regarding the action that will arouse the subsequent characters' reactions. If in literary terms the conflict is defined as the struggle against opposing forces, it is significant that in this case those opposed forces embody black children against white children. Is it possible for them to be friends? The conflict as a result is twofold: On the one hand, we find Clover's own internal conflict about overcoming her fears and talking to the white girl. On the other, there is the conflict of person-against-society: Can Clover defy social and racial historical conventions? Can she climb over that fence and overlook the barriers between black and white people? In fact, what Clover and Annie eventually do by becoming friends is to disregard the old beliefs and take a first step towards putting an end to that fence that keep people apart.

In The Other Side we find that conflict is mainly caused by social and racial issues, but also by the natural growth of a young girl. Clover is a full developed character with the complexities of an African American child maturing in the United States some time presumably in the 1960s or 1970s. These decades are characterized by tension and despair among African Americans. Although the 1950s had been a decade marked by historic progress in the campaign for racial justice, in much of the country, as Walter R. Allen and Reynolds Farley indicate, "blacks could not attend the same schools, eat at the same restaurants, or stay at the same hotels as whites. Black Americans were also 
denied opportunities in education and employment and, in Southern states, their voting rights” (1986: 278). Thus, the struggle to build a society free of persecutions and discrimination against blacks was far from finished and it would carry on into the 1960s. Thanks to the emergence and the influence of prominent leaders such as President John F. Kennedy and Martin Luther King, Jr., the African Americans' demands for equality and change came to be recognized as the nation's pre-eminent challenge (Rosenberg 2006: 212). However, both leaders were murdered and by then, Malcolm X was proclaiming that a more militant approach could be used to gain civil rights. Soon after, the Civil Rights Movements took place and in the 1970s students' protest and the Black Power movement expanded.

While Woodson does not explicitly portray any social or political issue, she makes Clover's traits and experiences believable and as the story goes by, we come to know her well through the words she says, her thoughts and her actions. Woodson relies on imagery, appealing to the reader's senses, to give us different impressions of the protagonist's personality. Based on her tone and her choice of details, she stirs the reader's imagination. In this way, we can sense Clover's growth throughout the story. Whereas at the beginning we infer her young mind through her observations, her childish use of the language and her way of recalling her mom's warnings; at the end of the book her actions and comments demonstrate her development as a character.

To illustrate these points, we see how Clover at first expresses her thoughts through sentence structure that reflect her young age. She says, for instance:

She never sat on that fence with anybody, that girl didn't. (Woodson 2001a: 4)

Or

She looked sad sometimes, that girl did. (Woodson 2001a: 8)

Through these statements not only is she articulating her thoughts in order to reaffirm herself, but also revealing her concern about that unknown white girl who seems lonely and blue. Furthermore, this same concern brings to light Clover's warm heart, inner curiosity and feeling of uncertainty on how to act. This is evident again when she recalls the time when they were jumping rope and Annie asked if she could play:

And my friend Sandra said no

without even asking the rest of us. 
I don't know what I would have said.

Maybe yes. Maybe no. (Woodson 2001a: 6)

Clover's words invite the reader to reflect with her about her dilemma. She is having a hard time understanding the whole racial issue. Some of the questions she might want to answer could be: Would you play with a person from the other side of the fence? Or rather, why would you not play with a person who has a different skin color? And why is there such a distance between black and white people? The fact that Clover feels bothered by her friend Sandra's reply reveals that she does not necessarily agree with the group's decision and she is an independent thinker.

Clover's initial way to sort out her problem is to ask her mom. Woodson again portrays a typical reaction in any given child, not just an African American one. And it is here when the writer makes an explicit critique of the history of segregation in America through the mother's response to her daughter: “...that's the way things have always been” (Woodson 2001a: 8), she says. This simple statement can be subject to different interpretations. As a child, Clover might infer that this is one of those complicated matters about which grown-ups avoid talking. However, as the curious girl that she is, there is another question that it is still pending even though she does not utter it: Why? Why have things always been that way? One of Woodson's achievements is her ability to trigger questions in the young reader's mind regardless of his or her cultural background or skin color. Another achievement is her subtle way of pointing out the past of injustice and discrimination that many African Americans suffered. In fact, she does this without even mentioning it. This is something that the adults know and what we are more likely to interpret out of the mother's statement. Certainly, we understand that the mother's first reaction is to protect her daughter. She does not want to tell her, at least not yet, that there is distance between blacks and whites because in the past blacks were taken as slaves by whites; there is distance because blacks were disregarded as human beings and considered inferior. Ultimately, there is distance because there are old wounds that still have not healed and possibly too because blacks themselves now choose to have that distance as a way to feel safe. Again, this is a significant reflection for every reader to make, not just an African American one.

But Woodson's story goes further than that. It is not her intention to instigate hatred or accuse anybody. On the contrary, the message in her picture book is one of optimism. 
As Cindy Giorgis and Nancy Johnson indicate, the author's "hopeful child's voice [and the illustrator] E.B. Lewis' watercolors capture the powerful mood of the story, the longing for friendship revealed by the girls’ body language” (2001a: 310). As already mentioned, Woodson's message echoes Du Bois' philosophy that considers that "the history of the American Negro is the history of his strife. [...] He simply wishes to make it possible for a man to be both a Negro and an American, without being cursed and spit upon by his fellows, without having the doors of Opportunity closed roughly in his face” (1903: 5). There is no doubt that among the themes of the book are attempts to support the ongoing struggle for equality, racial pride, strength and self-definition, but also interracial relationships, the role of the family and the community in the shaping of identity, and the role of education for both black and white children. For Du Bois, African American people are gifted with a second-sight. They can develop a double consciousness that allow them to be proud of their heritage while at the same time be American; that means living in the United States together with everybody else no matter the racial designation.

For Clover, Annie is like an enigma that she wants to decipher but does not know how to start. The important thing is that she is willing to try. She narrates how that summer

(o)n rainy days that girl sat on the fence in a raincoat.

She let herself get all wet and acted like she didn't even care.

Sometimes I saw her dancing around in puddles,

splashing and laughing. (Woodson 2001a: 9)

Clover is puzzled about how someone who lives so close can feel so distant and foreign to her. Here the author portrays a contrast between the two girls, and how Clover is in the process of developing that double consciousness that would let her figure out the white girl. It is significant that Annie is portrayed as the other, that is, the different one. On the contrary, Clover, as the self, appears inside her house looking out through the window. The watercolor illustrations are also crucial at this point. They set a tone of warmth, happiness and love. E.B. Lewis gives the reader a glimpse of Clover's home paying attention to details such as the four-tray shelf full of books, the book on the ottoman next to the armchair as if someone is currently reading it, the xylophone on the floor, and the picture frames. They symbolize knowledge, dignity, creativity, selfesteem, and most importantly, they break old stereotypes about black people related to 
their lack of interest in reading and learning or their poor living conditions. In The Other Side, home is a comfort zone.

On the other hand, it is necessary to pay attention to Clover's words on this page. As Nancy D. Tolson puts it, "a good picture book for children consists of illustrations that validate the words and vice versa, creating a much fuller understanding for the child” (2008: 38). Clover says:

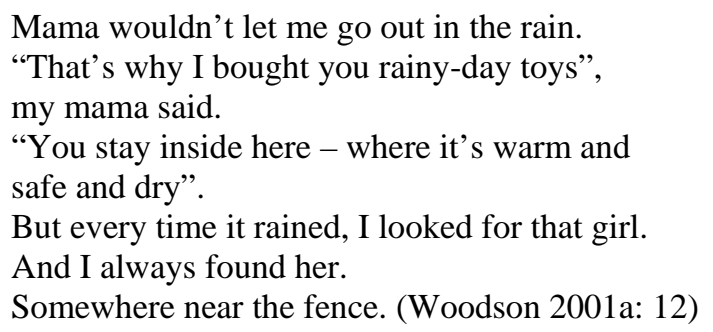

The author's use of language here illustrates the previous ideas about Clover's mom taking good care of her but also the child's restless mind and desire to go outside. The use of "but" at the beginning of the fourth sentence reveals Clover' slight rebellious attitude. Her mom's words do not comfort her at this moment. It seems as if there is something else in her head, as if she could not stop thinking about that girl on the other side of the fence. The rain is both outside and in her own thoughts. Woodson's language style in this excerpt can be related to Henry Louis Gates, Jr's theory of Signifyin(g), a uniquely black rhetorical concept, entirely textual or linguistic, rooted in the black vernacular tradition by which a second statement or figure repeats, or tropes, or reverses the first (Gates 1987: 49). In black vernacular, Signifying is verbal play. It is a rhetorical strategy, a sign that words cannot be trusted, that even the most literal utterance allows room for interpretation. In other words, what is said by a person must be understood in terms of context and other factors, rather than in and of itself. In this case, the fence stands up as a barrier that separates people but further than that, as an obstacle that also impedes access to knowledge. Clover becomes aware of her lack of understanding and every time she is confused (every time it rains), she tries to find an answer (she looks for that girl), and that answer is always near the fence. As a result, she realizes that the fence is the key and therefore, she has a strong desire to overcome it. Rising above the fence means defeating separation and inequality but over all, defeating ignorance. 
Similarly, a double reading can also be done on the following page of the book when Clover narrates:

Someplace in the middle of the summer, the rain stopped.

When I walked outside, the grass was damp

and the sun was already high up in the sky.

And I stood there with my hands up in the air.

I felt brave that day. I felt free.

Following Gates' theory of Signifying, the fact that the rain stopped and the sun began to shine can be read as the end of Clover's conflict. She has made up her mind. Now she feels free to do what she wants to do. For that reason, it is not without significance, that on the next page the climax of the story takes place: Clover gathers her courage, approaches the fence and talks to Annie for the first time.

As the story progresses, in the last part of the book, Clover shows her growth and mental development. She becomes friends with Annie, sits on the fence with her, dares to disregard Sandra and her other African American friends and even succeeds eventually in integrating Annie to the group by playing all together. In the very end, what was originally a barrier becomes a link between the two sides. The author leaves a final hopeful message for the reader through Annie and Clover's words:

\footnotetext{
"Someday somebody's going to come along and knock this old fence down”. Annie said.

And I nodded. “Yeah”, I said. “Someday”. (Woodson 2001a: 29)
}

From a literary point of view, when the reader is assured that all is well and will continue to be, we can say that the denouement is closed, or that the plot has a closed ending. In this case, the tying of the loose ends is thoroughly optimistic. There is no anxiety for black or white children on the last page of the story. It ends with Clover and Annie imagining a fenceless world. Both of them agree on the idea of knocking the fence down, assuming that it is old, from a different era and not from their own. Likewise, it is important that it is Annie the one who stated the idea first and not Clover showing thus a similarity between the viewpoints of the two girls.

Along this line of argument, we see how the first conflict in the story has been solved. Clover has come to terms with the racial reality in which she lives, she has acquired a new outlook on life -she has been brave to become friends with Annie and sit on the fence; all that means new knowledge. By contrast, the second conflict, the social and racial issues are still pending. The idea of sitting on the fence symbolizes the girls 
coming to terms with the fact that racism exists. Knocking the fence down would symbolize the end of it. The pictures here show us that Clover and Annie are not alone. There are four more girls sitting on the fence or playing around it. This issue is one that affects them too. As Clover and Annie talk, their friends listen to them. They all hope for the fence to be demolished some day.

To sum up, it is evident that Woodson's narrative style aligns with the Black Arts Movements and aesthetic. While as Violet J. Harris points out "a single Black aesthetic does not exist [and] rather, some core tenets can be found in the philosophies espoused by individuals" (2007: 1018); in The Other Side it is evident how the author's political views lead her to the literary objective of enveloping black children in a sense of respect, pride and love throughout the story. In consequence, Woodson's story not only is grounded in the African American experience but also attempts to deconstruct and reconstruct what it means to be a black person in a white society. In addition, the plot, representation of characters, point of view, setting, and tone aim to encourage and agitate positive thoughts and actions into black children's lives. As we have seen, The Other Side portrays the initiation of a child's racial reality in the United States. It presents a story that is necessary in order for black children to receive a more realistic view of the world that surrounds them. In this way, Woodson's book educates African American children who in the past often "felt ignored, mentally abused and confused from exposure to books that are invisible to their child's identity” (Tolson 2008: 2). The next question then that needs to be addressed is why it should be implied that the target audience of The Other Side is only African American young readers. Why should not European and American white children read it? This book is a tool of reflection and enrichment that demonstrates racial and cultural understanding for all children. It portrays themes that affect all human beings no matter the racial designation. By reading a book written from the perspective of an African American girl in children's terms, young white readers also could gain an understanding of how all children have similar concerns as they grow up. European and American white children could thus begin to reflect on the past of oppression and discrimination that black Americans endured. Clove and Annie represent a new generation of children who are brave to disregard the skin color historical differences and forge a friendship. The Other Side is thus a book with multicultural characters and themes that can be regarded as an 
aesthetic exploration of the human experience in the process of the acquisition of knowledge. That is what makes it universal.

\section{REFERENCES}

Allen, W.R. and Farley R. 1986. "The shifting social and economic tides of black America, 1950-1980”. Annual Review of Sociology 12, 277-306.

Bishop, R.S. 2007. Free Within Ourselves: The Development of African American Children's Literature. Westport, Conn: Greenwood Press.

Casement, R. 2003. “Jacqueline Woodson: Real characters, real voices”. Language Arts 81 (1), 81-83.

Du Bois, W.E.B. 1996. The Souls of the Black Folk. (1903). New York: Penguin Books.

Gates Jr., H.L. 1987. Figures in Black. Words, Signs and the "Racial” Self. New York: Oxford University Press.

Giorgis, C. and Johnson N. 2001. “Children’s books: Finding a place”. The Reading Teacher 55 (3), 304-311.

Harris, V.J. 2007. "Master narratives and oppositional texts: Aesthetics and black literature for youth”. In Bresler, L. (Ed.) International Handbook of Research in Arts Education, vol. 2. Dordrecht, Netherlands: Springer, 1007-1020.

Henderson, L. 2005. "The black arts movement and African American young adult literature: An evaluation of narrative style”. Children's Literature in Education 36 (4), 299-323.

hooks, b. 2003. Rock my Soul: Black People and Self-Esteem. New York: Washington Square Press.

Lazar, G. 1993. Literature and Language Teaching. Cambridge. Cambridge University Press.

Manuel, C. 2009. “bell hooks’s children's literature: Writing to transform the world at its root”. In Davidson M.G. and G. Yancy (Eds.) Critical Perspectives on bell hooks. New York and London: Routledge, 95-107. 
Natov, R. and De Lunca G. 1987. “An interview with John Steptoe”. The Lion and the Unicorn 11, 1, 122-129.

Rosenberg, J. 2006. How Far the Promised Land? Princeton: Princeton University Press.

Smith, C.L. 2008. "Author interview: Neal A. Lester on Once Upon a Time in a Different World”. 22 March 2012 <http://cynthialeitichsmith.blogspot.com.es/ 2008/06/author-interview-neal-lester-on-once.html>

Tolson, N.D. 2008. Black Children's Literature got the Blues: The Creativity of Black Writers and Illustrators. New York: Peter Lang.

Woodson, J. 2001a. The Other Side. New York: The Penguin Group.

Woodson, J. 2001b. “Fictions”. Obsidian III 3 (1), 49.

Received: 19 September 2011

Accepted: 10 May 2012

Cite this article as:

Reyes Torres, A. 2012. “Jacqueline Woodson's narrative style in The Other Side: An African American picture book for children”. Language Value 4 (2), 23-37. Jaume I University ePress: Castelló, Spain. http://www.e-revistes.uji.es/languagevalue. DOI: http://dx.doi.org/10.6035/ LanguageV.2012.4.2.3

ISSN 1989-7103

Articles are copyrighted by their respective authors 